DOI: https://doi.org/10.34069/AI/2021.42.06.6

How to Cite:

Ilchenko, O., Tkach, P., Sinna, L., Kadaner, O., \& Overchuk, O. (2021). Interpretation potential of mass media metaphor. Amazonia Investiga, 10(42), 56-68. https://doi.org/10.34069/AI/2021.42.06.6

\title{
Interpretation potential of mass media metaphor
}

\section{Інтерпретаційний потенціал метафори масмедіа}

Received: May 11, 2021

\section{Abstract}

The article is devoted to the analysis of the interpretation possibilities of the mass media metaphor. The aim of the work is to identify the semantic spheres that beget a metaphor in the modern language of the Ukrainian mass media. This work demonstrates the mechanism of metaphor production: components of a new meaning, components of metaphorical meaning, and the structure of metaphorical transference. The problems associated with the interpretation of metaphors are considered. The cognitive process of creating the investigated units represents the types of metaphorical transference. The metaphor is designed to simplify the process of perceiving complex new material. In 2000-2020 a new wave of metaphorical productivity was marked by the terms of the natural sciences during the timeframe of the research. As a result of the analysis, the metaphors of the political and economic discourses of the mass media were investigated, taking into account the semantic, cognitive-pragmatic approaches. On the basis of this material, the main trends in the development
Accepted: May 26, 2021

Written by:
Olena Ilchenko $^{24}$
https://orcid.org/0000-0002-5467-8883
Polina Tkach $^{25}$
https://orcid.org/0000-0003-4377-5335
Liudmyla Sinna $^{26}$
https://orcid.org/0000-0002-0407-1995
Oksana Kadaner ${ }^{27}$
https://orcid.org/0000-0001-8671-284X
Olena Overchuk ${ }^{28}$
https://orcid.org/0000-0003-4859-0452

\section{Анотація}

Стаття присвячена аналізу інтерпретаційних можливостей метафори масмедіа. Мета роботи полягає у визначенні семантичних сфер, які породжують метафору в сучасному мовленні українських масмедіа. У розвідці продемонстровано механізм творення метафори: компоненти нового змісту, компоненти метафоричного значення, структуру метафоричного перенесення. Розглянуто проблеми, пов'язані із трактуванням метафор. Когнітивний процес створення досліджуваних одиниць представляе типи метафоричного перенесення. Визначено, що метафора покликана спростити процес сприйняття складного нового матеріалу. У 2000-2020 pp. новою хвилею метафоричної продуктивності відзначено терміни природничих наук. У роботі досліджено метафори політичного й економічного дискурсів масмедіа із урахуванням семантичного, когнітивнопрагматичного підходів. У результаті проведеного аналізу виявлено головні тенденції розвитку сучасного мовлення

\footnotetext{
${ }^{24} \mathrm{PhD}$ in Philology, Assistant Professor at the Department of Philology, Translation and Strategic Communications of the National Academy of the National Guard of Ukraine, Kharkiv, Ukraine.

${ }^{25} \mathrm{PhD}$ in Philology, Associate Professor, Professor at the Department of Philology, Translation and Strategic Communications of the National Academy of the National Guard of Ukraine, Kharkiv, Ukraine.

${ }^{26}$ Assistant Professor at the Department of Philology, Translation and Strategic Communications of the National Academy of the National Guard of Ukraine, Kharkiv, Ukraine.

${ }^{27} \mathrm{PhD}$ in Philology, Associate Professor, Assistant Professor at the Department of Foreign Languages № 1, Yaroslav Mudryi National Law University, Kharkiv, Ukraine.

${ }^{28}$ Ph.D. in Philology, Assistant Professor at the Depatment of Ukrainian Studies of the Karkiv National University of Internal Affair, Kharkiv, Ukraine.
} 


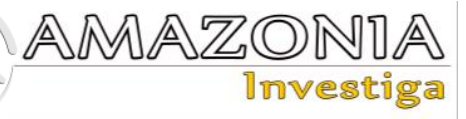

of the modern language of the Ukrainian mass media are revealed and the interpretative and evaluative potential of the media metaphor is determined.

Key words: economic discourse, language of mass media, metaphor, political discourse, types of metaphorical transferences.

\section{Introduction}

Language reflects the social development of the people and the state. It records all the turning points in the life of society. The first two decades of the XXI century are characterized in Ukraine by significant changes that have affected not only social development, but also the language, particularly its lexical and semantic level. The language of the media is a verbal reflection of the relevant social factors - a textualized response to life. Among the verbal means of displaying public life in the mass media language of the XXI century an important place is occupied by metaphors.

The relevance of the topic is conditioned by the presence of metaphors in the mass media language that demonstrate the potential of this language, its creativity, the connection of the language with public life. Therefore, such metaphors require a detailed comprehensive analysis from the standpoint of the modern linguistic interpretation of the units under study.

The purpose of this work is to identify the semantic spheres that beget metaphorical meaning in the political and economic discourse of the mass media over the period 2000-2020. українських масмедіа й визначено інтерпретаційний оцінний потенціал медійної метафори.

Ключові слова: мовлення масмедіа, метафора, типи метафоричного перенесення, політичний дискурс, економічний дискурс.

This will reveal the interpretative possibilities of the metaphor and repeat the cognitive-linguistic way of its creation.

\section{Literature Review}

The metaphor in the language of mass media has been the subject of active research by many linguists: Kh. Datsyshyn (2005), O. Ilchenko (2019; 2012), L. Kudriavtseva et al (2005), I. Filatenko (2003), O. Chadiuk (2005), A. Chudinov (2003), O. Styshov (2016), and others. Metaphor of the Ukrainian mass media in 2000-2020 in terms of studying the interpretation potential has not been a subject of study.

\section{Theoretical Framework}

Metaphor has been studied for a long time: Aristotle gave the first definition of metaphor, which marked the beginning of a serious study of the mechanism of semantic changes in the language. Metaphor is the result of the relationship between two meanings of a word, a vivid example of dynamics in the field of lexical semantics (Hak, 1988, p. 11).

Table 1.

Periodization of the formation of metaphorology.

\begin{tabular}{|c|c|c|c|}
\hline Period & & Researchers & Main achievements \\
\hline I & Antique & $\begin{array}{l}\text { Aristotle, Quintilian, Cicero (Lahuta, 2003, p. 16- } \\
\text { 22) }\end{array}$ & $\begin{array}{l}\text { Study of metaphor as a rhetorical } \\
\text { device; obtaining the first } \\
\text { definition: the transfer of signs in } \\
\text { connection with the similarity of } \\
\text { one object with another }\end{array}$ \\
\hline II & $\begin{array}{l}\text { Medieval (late } \\
5^{\text {th }} \text { century - } \\
\text { middle } 17^{\text {th }} \\
\text { century) }\end{array}$ & $\begin{array}{l}\text { F. Melanchthon, I. Sevilskyi, G. Hirobosk (Lahuta, } \\
\text { 2003, p. 22-27) }\end{array}$ & $\begin{array}{l}\text { A clear and consistent definition } \\
\text { of the "metaphor-word" with a } \\
\text { description of its objective limits; } \\
\text { systematization of figures and } \\
\text { tropes; regulation of terminology }\end{array}$ \\
\hline III & $\begin{array}{l}\text { Modern times } \\
\text { (late } 17^{\text {th }} \\
\text { century - late } \\
19^{\text {th }} \text { century) }\end{array}$ & $\begin{array}{l}\text { D. Gartley, J. Locke, J. Mill (Lahuta, 2003, p. 27- } \\
\text { 29) }\end{array}$ & $\begin{array}{l}\text { Revealing the connections } \\
\text { between the associative nature of } \\
\text { thinking and the creation of a } \\
\text { metaphor; use of metaphor in } \\
\text { scientific and fictional texts }\end{array}$ \\
\hline
\end{tabular}




\begin{tabular}{|c|c|c|c|c|c|}
\hline \multirow{5}{*}{ IV } & \multirow{5}{*}{$\begin{array}{l}\text { Modern }\left(20^{\text {th }}\right. \\
\text { century }-21^{\text {st }} \\
\text { century })\end{array}$} & \multirow{5}{*}{$\begin{array}{l}\text { Learning } \\
\text { Aspects }\end{array}$} & Structural & $\begin{array}{l}\text { N. Arutiunova (1990), } \\
\text { D. Bickerton (1990), } \\
\text { V. Hak (1988), } \\
\text { T. Yeshchenko (1999), } \\
\text { and others } \\
\text { V. Hak (1988), } \\
\text { Kh. Datsyshyn (2005), } \\
\text { L. Kravets (2012), } \\
\text { S. Talko (2016), } \\
\text { V. Teliia (1988), } \\
\text { P. Ricoeur (1990), and } \\
\text { others }\end{array}$ & $\begin{array}{l}\text { Allocation of semantic types of } \\
\text { metaphor according to the } \\
\text { original meaning of the word and } \\
\text { the new one }\end{array}$ \\
\hline & & & Functional & $\begin{array}{l}\text { N. Arutiunova (1990), } \\
\text { D. Bickerton (1990), } \\
\text { V. Hak (1988), } \\
\text { T. Yeshchenko (1999), } \\
\text { and others }\end{array}$ & $\begin{array}{l}\text { Two directions of the use of } \\
\text { metaphor in the language system: } \\
\text { the first - the metaphor is a } \\
\text { means of nomination, the second } \\
\text { - depends on the functional style } \\
\text { in which the metaphor is used }\end{array}$ \\
\hline & & & Cognitive & $\begin{array}{l}\text { V. Hak (1988), } \\
\text { J. Lakoff and } \\
\text { M. Johnson (1990), } \\
\text { E. McCormack (1990), } \\
\text { and others }\end{array}$ & $\begin{array}{l}\text { The emergence of a metaphor is } \\
\text { associated with the peculiarities } \\
\text { of human thinking: a metaphor is } \\
\text { one of the ways of organizing } \\
\text { cognitive activity }\end{array}$ \\
\hline & & & Pragmatic & $\begin{array}{l}\text { T. Yeshchenko (1999), } \\
\text { Kh. Datsyshyn (2005), } \\
\text { S. Levin (1990), and } \\
\text { others }\end{array}$ & $\begin{array}{l}\text { Analysis of the mechanisms that } \\
\text { connect the language with the } \\
\text { context of its use, that is, the use } \\
\text { of a metaphor is determined by } \\
\text { the rules of using the language, } \\
\text { and not by the semantic structure }\end{array}$ \\
\hline & & & $\begin{array}{l}\text { Psycholingu } \\
\text { istic }\end{array}$ & $\begin{array}{l}\text { N. Arutiunova (1990), } \\
\text { P. Ricoeur (1990), and } \\
\text { others }\end{array}$ & $\begin{array}{l}\text { Supplementing the semantic } \\
\text { theory of metaphor with the } \\
\text { analysis of the sensory aspect of } \\
\text { the image, the associative } \\
\text { mechanism }\end{array}$ \\
\hline
\end{tabular}

The level of modern science of language and speech convinces: solving the problem of studying a metaphor requires an integrated approach, which implies representatives of different sciences bringing together (Shakhnarovych, Yurieva, 1988, p. 108). The metaphor is being studied in philosophy, logic, psychology, psychoanalysis, literary criticism, literary criticism, rhetoric, linguistic philosophy, various schools of linguistics (Arutiunova, 1990, p. 5).

An independent scientific discipline of metaphorology has even appeared, based on philosophical, logical, psychological and linguistic interdisciplinary connections (Kravets, 2005, p. 214; Lahuta, 2003). Considering the duration, "although not a systematic approach" (Bickerton, 1990, p. 284), of the study of metaphor, there is a corresponding periodization of the formation of metaphorology. There are four periods: antique, medieval, the period of the New Time and the modern (Lahuta, 2003) (see table 1).

Interpreting the concept of "metaphor", the entries of the modern period demonstrate: metaphor is understood in a narrow and broad sense. Metaphor (gr. Metaphora - transfer) is the process of transferring the form of a linguistic unit or the design of a linguistic category from one object, phenomenon, action or feature to another based on a certain similarity between these objects for the purpose of characterization or nomination (Arutiunova, 2003, p. 233; Taranenko, 2007, p. 350). In a broad sense, the term "metaphor" is used to denote a figurative meaning in general (Arutiunova, 2003, p. 233; Taranenko, 2007, p. 352).

The research of the metaphor in this work is conducted authors taking into account its two main functions: characterizing (aesthetic, expressive, evaluative) and nominative (designating concepts that do not have a name) (Arutiunova, 2003; Taranenko, 2007, p. 352). Cognitivists (see table 1) argue that the metaphor arises in connection with the deep features of human thinking (Hak, 1988, p. 11). It appears not because it is needed, not because it is indispensable, but because it is inherent for human thinking and language. Research in the field of psychology proves that "metaphors reach the affected areas of consciousness faster than 


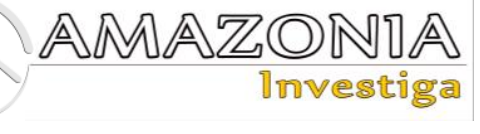

their direct logical equivalents" (Lahuta, 2003, p. 81). A person does not perceive phenomena in their pure form, but endows them with certain properties (Hak, 1988, p. 13). It is only later the authors derive from the metaphor "benefit for their creativity" (Hak, 1988, p. 12). Linguists add: the speaker uses a metaphor to designate concepts "that have not yet become the property of the dictionary and do not simulate the public's reaction" (Yeshchenko, 1999, p. 276). It means the motives for creating a metaphor can be not only an epistemological search, but also desire to present certain concepts in a new, original way, to designate certain concepts expressively (Yeshchenko, 1999, p. 277). Concerning the functions of metaphor in the language of mass media, we can conclude: a metaphor performs an expressive, evaluative, nominative function, provides the effect of novelty. Researchers note also other functions of metaphor, in particular, the economy of linguistic means, informative, text-forming, which consists in the ability of metaphorical expression to continue (Vynnyk, 2007, p. 4). Kh. Datsyshyn experimentally proves that metaphor "conveys more information than literal expression and at the same time focuses on the most essential, from the point of view of the subject of speech, signs of reality" (Datsyshyn, 2005, p. 9).

Each recipient decodes the metaphor differently. "To understand a metaphor means to some extent to trace the path of its creation apocryphally <...>" (Shakhnarovych, Yurieva, 1988, p. 109). For this it is necessary to determine: 1) the components of the formation of a new meaning; 2) components of metaphorical meaning; 3 ) the structure of the metaphor; 4) the mechanism of metaphorical transfer.

1. Metaphor is one of the means of generating new meaning. This process involves four components: the category of object-1, properties of the category of object-1, category of the object-2, properties of the category of object-2 (Arutiunova, 2003, p. 233).

The metaphor searches for a similar element (Arutiunova, 2003, p. 233; Taranenko, 2007, p. 351; Shakhnarovych, Yurieva, 1988, p. 111; Chadiuk, 2005, p. 5) of two compared objects or reveals the associations on which the metaphor is based (Kravets, 2005; Ricoeur, 1990).

$\mathrm{P}$. Ricoeur defines a fundamental difference between similarity and association. This difference seems to lie in the opposition of the verbal to the non-verbal (Ricoeur, 1990, p. 221). It is worth agreeing that a common component of the compared objects is non-verbal characteristics. P. Ricoeur understands visual, auditory and other sensory images as a common component (Ricoeur, 1990, p. 221).

A. Taranenko names the following signs of similarity in the metaphor: 1) by external similarity: shape, color, location, sounds, features of movement (movement), functions, quantity; 2) by the similarity of physiological and psychological impressions from the perception of various objects (subjectivity is higher than when creating other metaphors); transfers from the concrete physical world to the spheres of psychological and social life that are inaccessible for direct sensory perception, abstract relations, in particular from space to time; transfers due to the actualization of a secondary, often indistinct associative feature, in particular of an emotional and evaluative nature, with almost complete deactualization, but with the subject-logical basis of the original meaning; 3 ) similarity that does not exist in reality (taking into account its subjective transformations at the level of consciousness), but which is only desirable for the speaker, in particular during the adress and the formation of their own names (Taranenko, 2007, p. 351).

Thus, the source of the new meaning of the metaphor is comparison (Arutiunova, 2003, p. 233; Talko, 2009, p. 5; Teliia 1988, p. 111). The task of the recipient is to "skip" someone else's comparison from the perspective of their own experience and knowledge and come to the same conclusion as the creator of the metaphor (Teliia, 1988, p. 109).

2. The metaphorical meaning determines the principle of proportion (Arutiunova, 2003, p. 234; Ricoeur, 1990). The interaction of two different classes of denotations (or one, if we are talking about a metaphor in a broad sense, then the concept of "metaphor" includes metonymy as a means of producing a figurative meaning) leads to the semantic ambiguity of the metaphor (first of all, we are talking about a "alive" metaphor) (Arutiunova, 2003, p. 234; Shakhnarovych, Yurieva, 1988, p. 109). This typical feature of the metaphor complicates its interpretation and limits its usage in functional styles. The characteristic of one of the denotations (one of the three components of the metaphorical meaning is the category of denotation-1; the category of denotation-2; the characteristic of the denotation named in the metaphor) can be a national component of the consciousness of native speakers. It means it can belong to the 
collection of their common ideas about the corresponding category of objects, including mythological, cultural and emotionalevaluative connotations (Arutiunova, 2003, p. 234; Kravets, 2005, p. 213).

3. The structure of the metaphor is determined by two components: the metaphorical meaning is a property of the actual subject and the image of the auxiliary subject of the metaphor (Arutiunova, 2003, p. 234).

4. Metaphorical transfer, as a rule, is supplemented by a three-term structure: initial word $\rightarrow$ transitional concept $\leftarrow$ resultative word (Hak, 1988, p. 14). Metaphorization is the semantic model of the formation of a figurative meaning in a lexeme, which causes the emergence of a metaphorical lexical-semantic version, namely, a metaphor (Chadiuk, 2005, p. 5).

Researchers note that "when metaphorizing presents we should not $\langle. .$.$\rangle look for common$ schemes inherent in the dictionary definitions of two words" (Hak, 1988, p. 15), because a metaphor is set in on the basis of vague concepts that human cognition operates with. There is also an opposite opinion regarding the meaning of a metaphor: "<...> Metaphors mean only that (or no more) what the word-components, taken in their literal meaning, mean" (Davidson, 1990, p. 173).

A metaphor reflects the relationship between two meanings of a word. The types of metaphorical transfers are determined by the original and new meaning of the word. In the process of studying the types of metaphor, it is worth distinguishing between transfers of common semantic categories and transfers of individual words. Transfers are reflected in the etymology of the word, in the polysemy of the word, in phraseological combinations and in a word usage (Hak, 1988, p. 17).

Metaphorical transfers in the language are implemented according to certain patterns. The main generalized types of transfers were defined in ancient times: Aristotle called the metaphor "transfer of an unusual name either from genus to species, or from species to genus, or from species to species, or by analogy" (Aristotle, 2000, p. 54); Quintilian identified four kinds of metaphors: from living to non-living, from nonliving to living, within the living and within the non-living (Kravets, 2005, p. 214; Taranenko, 2007, p. 351). In modern studies, these types are supplemented and detailed (Arutiunova, 2003; Kravets, 2005; Solhanik, 1980; Hak, 1988). S. Ulman identifies the following types of metaphorization: a) anthroporphic metaphors; b) zoomorphic metaphors; c) transfer from concrete to abstract; d) synesthetic; e) active metaphorization of the vocabulary of that sphere of life, which at a certain period attracts special attention of society (Taranenko, 2007, p. 351; Hak, 1988, p. 17), demonstrating "the place of a certain sphere on the scale of social values of society" (Taranenko, 2007, p. 351); J. Lakoff and M. Johnson distinguish orientational metaphors: "up - down", "inside - outside", "front side back side", "deep - shallow", "central peripheral" (Lakoff, Johnson, 1990). Other researchers distinguish geographic, meteorological, biomorphic, technical, sociomorphic metaphors, etc. (Hak, 1988, 17).

Transfers are not one-vectored, but nevertheless, in a certain direction they occur more often than in another one (Hak, 1988, p. 18). A. Taranenko notes that the metaphorization of the vocabulary of sports, space, informatics, medicine is a dynamic process now (Taranenko, 2007, pp. 351-352).

Scientists define a number of patterns of metaphorization of the meaning of a word: the physical attribute of an object is transferred to a person, inducing the designation of the mental characteristics of a person; an attribute of an object is converted into an attribute of an abstract concept; a sign or action of a person refers to objects, natural phenomena, abstract concepts (the principle of anthropomorphism); features of nature are transferred to humans (Arutiunova, 2003 , p. 235). Metaphorization processes are not the same in different types of discourse.

Researchers of the metaphor note that in this constant transfer of concepts from one sphere to another, not only the flexibility of the human mind turns out; it is a necessity for the very understanding of reality (Hak, 1988, p. 13).

\section{Methodology}

To achieve this goal, it is used the appropriate research methods - linguistic description, based on observation of the linguistic material; analysis and synthesis used in the description of metaphors; comparative method, due to which the basic theoretical foundations of the research are determined; the method of contextualsemantic analysis, which allows to take into account the context for figuring out the new metaphorical meaning of a word; the method of contextual (discursive) analysis, which is aimed at determining the functional load of mass media 
metaphors.

\section{Results and Discussion}

Interpretation of metaphor lies in finding common points in the comparison of objects the act of metaphorization. This act is expressed by the transfer of a certain attribute of one object, phenomenon, person to another, upon the availability of a common characteristic. A necessary condition for understanding the metaphor is that the addresser should take into consideration the addressee's factor, in the context of which the productivity of the type of metaphorical transfer and the interpretative result of the metaphor as a result of cognitivepragmatic effort depends on the characteristics of the discourse.

Thus, political discourse transforms the action of the corresponding political processes over the period 2000-2020 in Ukraine. And the language of the mass media synchronously reflects the constantly changing of political situation in the state. To assess and characterize political processes, the corresponding discourse actively brings about metaphorization of medical, military, cultural, sports vocabulary.

The medical industry in political discourse is represented by words indicating diseases, scientific achievements in the field of medicine, the names of drugs. Frequent use of the word syndrome is limited to the designation of a specific population group (Psychologists know the so-called "immigrant syndrome". A person, who has come to another country, at a certain stage, often begins to feel depressed, lonely, lost, feeling hopeless or ruined life... (Sierova, 2013) ${ }^{29}$; Afghan syndrome of post-Maidan Ukraine (Kobza, 2019); "Donetsk-Luhansk syndrome": what about our guys who survived the anti-terrorist operation (Volyn News Agency, 2014); Today, the syndrome of "polluted water" is relevant again. Experts analyze the stagnation in society, looking for reasons. Are there any parallels between the current state of Ukraine and a clear example of stagnation - during the reign of Leonid Brezhnev? (Stepula, 2011). Names of diseases and the word "disease" itself do not have such restrictions as the syndrome, for example, Five "diseases" of Ukrainian voters (Popova, 2018). Sharp, decisive, significant changes are characterized by used words with a figurative meaning, taken from the field of surgery: I am

${ }^{29}$ Translation of metaphors in all examples is made by us and links are made to original mass media materials sure that journalists, as anatomists, know very well the whole pathoanatomy of the Ukrainian state and the authorities in it. It is terrible. And if journalists can after becoming politicians carry out serious "surgical interventions", I think it would be very good (Kuznietsova, 2012). The medical terms from the branch of oncology emphasize that the issue is urgent and cannot be solved, because the socio-political realia proposed in the political discourse of the mass media borrow the signs of a complex disease, and with the appearance of metastases, it is incurable: Cancer of the Ukrainian Themis (Stepanishyn, 2019). Thus, the "medical" metaphor acquires a pejorative color and indicates a desire to eliminate the phenomenon for which metaphors are used in political discourse.

In modern political discourse, words representing military affairs are in the process of metaphorization. War acquires a secondary meaning "struggle", "unfriendly, hostile attitude", etc.: Russia's political war in Europe: agents of chaos and who controls them (research review) (Savchuk, 2017); battle - "confrontation of two parties": They [presidential candidates $P$. Poroshenko and V. Zelenskyi - authors] immediately rushed into battle (Newscast TNS, 2019). In the language of mass media among the words on military topics the authors of this work notice the word trench, used to express the meaning of "inaction" (However, as the Sehodnia newspaper notes, it is unlikely to drive the population into trade trenches (Bila, 2013)); minefield - "danger" (Yushchenko doesn't put pressure on Omelchenko, and Tymoshenko is on the minefield (Interfax-Ukraine, 2005)), etc. Since 2014 we have noticed a sharp decline in the performance of the "military" metaphor in the Ukrainian mass media, but this vocabulary has begun to be actively used in its direct meaning, compare: War in the east: 14 batters, 1 JFO [Joint Forces Operation - authors] fighter was killed, 2 occupiers were destroyed (War, 2019); "War is not a passion. This is my native pain" a photojournalist who filmed the Maidan and Donbass (Tymoshenko, 2020).

The political discourse of the mass media borrows words from the cultural continuum, which is formed by the names of various types of shows, words denoting actors and spectators, the corresponding premises, theatrical props, works of art and their elements, as well as words associated with puppet theater, circus (Andreichenko, 2011). The collected material 
demonstrates the functioning of such cultural vocabulary: stage curtain is a folding screen indicate the exposure "backstage" policy (Serhii Shvets unfolds the stage curtain (Newscast TNS, 2019); Behind the stage curtain of a show called "Analyzes" there remain many other requirements that Zelenskyi claimed about the current presidency and formulated state plans (Newscast TNS, 2019); theatre of the absurd Ukrainian politics (If you are Evil, is it permitted for you? or Theatre of the absurd in Odessa (Smolinska, 2019)); a puppeteer is one who "owns" Ukraine, and the theater, we assume, is whole Ukraine (The artistic and political performance "Election Halloween" took place under the walls of the Verkhovna Rada. Parliament was stormed by "political carcasses", "mysterious puppeteer" and their "puppets", and "athletes" and "professors" were dragged there by their collars. (Politychni, 2012)); puppet theatre - is Ukraine led by the president or another influential person, who is called a puppeteer (The world farther and further resembles a puppet theatre. Somewhere in obscure from time to time a mysterious puppeteer pulls strings, known only for him (Kostenko, 2007)); scenario - "development of events" (All these events took place under the same scenario (Bratushchak, 2017)); tour "retreats with citizens" (Poroshenko's "Tour". 10 stories about PR, which may be of interest to law enforcement (Bratushchak, 2017)); quartet denotes four participants in a political event (Lashchenko, 2020), etc. Thus, the "cultural" metaphor indicates the exposure of the true state of affairs in politics.

The productivity of metaphorical borrowings from the sports field is illustrated in particular by the following verbal units: one-sided game "miscalculation in political strategy" (\#Hroisman's government: One-sided game. How Poroshenko lost to the Cabinet. There is one kind of billiards - snooker. It is probably the most difficult and exquisite kind of billiards and at the same time is the perfect metaphor of current Ukrainian government (Romaniuk, 2018)); marathon, race - "competition" (Local elections 2020: video of the election marathon on Channel 24 (Local, 2020); The American leader spoke about Amy Klobushar, who announced her participation in the presidential race during the snowfall (Trump, 2019)); sport"favorite occupation" (It seems that disregard for the law - a favorite sport of Ukrainians (Huzar, 2014)), etc. The "sports" metaphor demonstrates the dynamism of the development of events in the political discourse of the mass media.
Lexemes, representing particularly the mentioned areas of metaphorical borrowing, acquire new figurative, contextually dependent (occasional) meanings. Such political metaphors do not go unseen by the recipients, because they are information-intensive and at the same time vivid, expressive and capable to express the corresponding characteristics.

The analysis of economic discourse showed that its linguistic fund is enriched by the special vocabulary of various industries, which in the language of the mass media "is used in two main aspects: literally and figuratively" (Solhanik, 1981 , p. 72). The figurative use of lexemes is subordinated to the objectives of the style of the mass media. "<..> The use of terms in a figurative sense, according to H. Solhanik, is one of the main and constant sources of replenishment of newspaper vocabulary, the development of our own newspaper lexical fund" (Solhanik, 1981, p. 73). The figurative meaning of words is represented particularly by metaphors, which functions are to "revive" the language of the mass media, to give it expressiveness, imagery, and this is harmoniously combined with the function of social assessment (Solhanik, 1981, pp. 73-74). In addition, the expressiveness acquired by the word serves as a means of attracting a reader/viewer audience. As a rule vocabulary from the natural, everyday life, medical, and military fields is undergone the process of metaphorization.

From a historical point of view, the role of the terms of the field of mathematics, physics, astronomy and other sciences in the development of the vocabulary of the literary language is important, but the research of $\mathrm{H}$. Solhanik (Solhanik, 1981) regarding the language of the press demonstrates: the mentioned exact and natural sciences do not have a deep influence on the replenishment of vocabulary of press, they are inferior to medical, cultural, sports, military terminology. This researcher assumes that the exact and natural sciences have fulfilled their historical mission; they have provided the language of the press with a large number of metaphorically reinterpreted newspaper words (Solhanik, 1981, p. 86). Obviously study of metaphors of economic discourse in mass media over the period 2000-2020 forms a new wave of metaphorization of the terms of the natural sciences. In particular, economic discourse uses the following words of this industry - climate, which is an integral part of the "meteorological vocabulary" (Solhanik, 1981, p. 88); ("We will stand side by side with Ukraine till it fights 


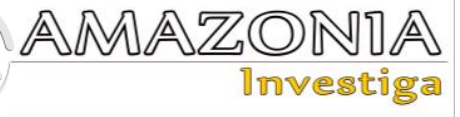

Russian aggression, strengthens the rule of law, creates a healthy investment climate, reforms the defense sector, fights misinformation and takes the necessary steps to ensure the ultimate victory of those on the sidelines of justice and dignity", it was said in a statement. (The United States, 2019), storm, wind, whirlwind, the semantic difference in the use of which is to express the power of the event and for indicating such event it is used this or that word (Solhanik, 1981, p. 88) ("It's a storm with two components, " said an IMF spokesman (IMF, 2008); And most likely it would have lasted even longer without success if the wind of great political changes had not blown. Unexpectedly for the financial market, the District Administrative Court made its decision just before the final round of the presidential election <...> (Korobkova, 2019) Tymoshenko will arrange a budget "storm" for Yatseniuk before the holidays (Tymoshenko, 2008); Will Ukraine be covered by an investment whirlwind in 2019 (Volska, 2019)); swale - in a metaphorical sense we use the imagery of nature (A system of voluntary fines can clean up the entire state system by acting as a truth and reconciliation commission, an approach used in many countries that are hopelessly stuck in a quagmire of corruption (Kalymon, 2016)); abyss (That is why we have heard since May 2015 and continue to hear scattered, not reasonable statements of senior officials about the end of the crisis and reaching the bottom of the economic abyss (Lanovyi, 2015)). "Natural" metaphors in the language of the mass media can lose their evaluative "gloss". There is a tendency: the newer the word in the in the language of the mass media, the higher its imagery in the process of metaphorization, because there is a close connection between the initial meaning and the effective one. The main feature of the use of this vocabulary is the serial nature of its metaphorization: whole thematic groups are undergone metaphorization, acquiring a homogeneous expressive-evaluative meaning. Individual uses supplement existing groups.

The metaphorization of everyday vocabulary is a widespread phenomenon in the language of the mass media, inasmuch as the metaphors based on this vocabulary are understandable to a wide audience: trap - <...> The country is in a state of "deflation trap" - an economic phenomenon characterized by the conditions of falling demand for goods and services of the enterprise - producers have to reduce production and sales prices (Brodovych, 2009); bag - Once you had a kind of "black bag" and now you take into account every penny (Shchelokov, 2015); laundry-How European banks became a part of the "big laundry" for dirty money from Russia (Moiseienko, 2019). The "everyday" metaphor in the economic discourse of the mass media has a high degree of negative evaluative meaning. This evaluative orientation of the use of "everyday" vocabulary in the mass media language can be explained by a general decrease in this category of vocabulary.

The "medical" vocabulary has a strong and profound influence on the language of the mass media. As in political discourse, in economic discourse this lexical category has negative evaluative specialization. In a figurative sense the following words are usually used: medicines - "Cure for corruption": how to fight bribery in Transcarpathia (Anti-corruption bulletin "Vasha Nadiya", 2016); sick - <..> Sick economy causes damage to their possessions (Lanovyi, 2016); heart - The heart of Ukrainian corruption is the prosecutor's office. How to snatch it? (Demchuk, 2015); anatomyJournalist Larysa Stupak interviewed Chop City Council economist Cheban Tetiana about the anatomy of bribery provocation by citizen Serhii Nikulin from Dnipropetrovsk city (Tribune, 2017); sedative - "Sedative" for the electorate salaries and pensions will be increased by force (Chorna, 2011). Optimistic mood, perhaps with irony demonstartes the following metaphors: recovery - Ukraine has introduced an adaptive quarantine recovery plan, which consists of 5 stages. It is important to constantly exchange experiences with other countries on the fight against coronavirus, economic recovery after COVID-19, business support, preservation and creation of new jobs (Ukraine, 2020). These lexemes are more imaginative than the previous block of examples of "medical" metaphors. An interesting tendency can be noticed: the more unexpected usage of the word in economic discourse, the more vivid it is.

Metaphorization of the military vocabulary in economic discourse demonstrates the standardization of the word usage war and its determinology. Metaphors are used as standard means of it: vodka wars (On the eve of the vodka war? (Tertychna, 2003)); tariff war (Demand for LVMH brands has been stable in recent years, which is not the case with Tiffany products - in the first quarter of this year the company's global profits declined by 3\%, and the "tariff war" between the US and China could worsen the company's situation even harder (Economic truth, 2019)); gas war (Russia's gas war must be won (Lanovyi, 2015)); price wars (Price wars and pandemics at the same time: what is special about the recent fall in oil prices? (Savkova, 
2020)). We observe the spread in economic discourse of such military terms as fight - The fight against the shadow, that is, commodity smuggling, has become a constant refrain of power in recent years (Economic truth, 2020); front - Statements and insides about imminent victories on the nuclear missile front flooded the Russian media (Bohapov, 2019).

The modern development of the language design of the economic discourse of the mass media is determined by the metaphorical types of transfer from different thematic categories of special vocabulary. This is due to extralinguistic factors. For the language of mass media an important driving force of such speech activity is social evaluativity, which manifests its nature, features, peculiarities. The action of the principle of social assessment and expressiveness predetermines the selection (in qualitative and quantitative characteristics) of lexical categories, in other words it determines the lexical system of the economic discourse of the mass media.

\section{Conclusions}

Language is a living organism that develops along with its speakers. This is a kind of sensitive matter that reflects social, political, economic changes in the life of the people. Analyzing changes in the language, first of all we deal with the language of mass media, which is a relay of popular science knowledge for the public, because mass media is a means of accelerating the assimilation of terminology, approbation of the expressive and evaluative means of language (speech).

A characteristic feature of the mass media language is a metaphor based on the comparison of two objects or categories of objects. Determining the objects to be compared and the manifestation of their common properties is a prerequisite for understanding the metaphor. For this it is necessary to mentally reconstruct the mechanism of creating a metaphor: to establish the components of generating a new meaning; to identify the components of metaphorical meaning; to find out the structure of metaphorical transfer and determine its mechanism.

The lexical system of the mass media language has an open character, the relative stability can be determined only for a certain period, which determines the constant necessity (urgency) of its research. Therefore, the analysis of the metaphors of political and economic discourses is a synchronous cross-section of the study of the Ukrainian mass media vocabulary over the period 2000-2020.

\section{Bibliographic references}

Andreichenko, O. I (2011). The metaphor of theater in modern political discourse: a cognitive aspect. Bulletin of Dnipropetrovsk University. Linguistics series, 11, Ed. 17, vol. 1, pp. 9-14. URL:

http://nbuv.gov.ua/UJRN/vdumo_2011_19_17

$\% 281 \% 29 \_4$

Anti-corruption bulletin "Vasha Nadiya" (2016). "Cure for Corruption": how to fight bribery in Transcarpathia.

URL: https://www.youtube.com/watch?v=nQcwXvFg qXQ

Aristotle, (2000). Poetics. Rhetoric. St. Petersburg: ABC. URL: https://docplayer.ru/26015680-Aristotelpoetika-ritorika-aristotel-poetika-ritorika-izdvo-azbuka-sankt-peterburg-2000-g-ritorikakniga-pervaya.html

Arutiunova, N. D. (1990). Metaphor and discourse. In Arutiunova, N. D., Zhurinskaia, M. A. (and others). Metaphor theory. Moscow: Progress, pp. 5-32. URL: http://tlf.msk.ru/school/mikhalych/teoriya_meta fory.htm

Arutiunova, N. D. (2003). Metaphor. In Karaulov, Yu. N. (and others). Russian language: encyclopedia. Moscow: Scientific Publishing House 'Great Russian Encyclopedia'. Repr. ed., pp. 233-236. URL: https://bigenc.ru/literature/text/2208483

Bickerton, D. (1990). An introduction to the linguistic theory of metaphor. In Arutiunova, N. D., Zhurinskaya, M. A. (and others). Metaphor theory. Moscow: Progress, pp. 284-306.

URL:

http://tlf.msk.ru/school/mikhalych/teoriya_meta fory.htm

Bila, I. (2013). Will the autumn hryvnia exchange rate be stable? (Press review). URL: https://www.radiosvoboda.org/a/25068259.html Bohapov, H. (2019). Russia claims imminent victories on the nuclear missile front-expert. ZN.UA. URL: https://zn.ua/ukr/WORLD/rosiyazayavlyaye-pro-blizki-peremogi-na-raketnoyadernomu-fronti-ekspert-302295_.html Bratushchak, O. (2017). Poroshenko's "tour". 10 stories about PR that may be of interest to law enforcement. Ukrainian truth. URL: https://www.pravda.com.ua/articles/2017/09/12/ 7154215/

Brodovych, S. (2009). Ukraine in the "deflation trap". Economic truth. . URL: https://www.epravda.com.ua/columns/2009/06/ 24/197380/

Chadiuk, O. M. (2005). Metaphor in the sphere 


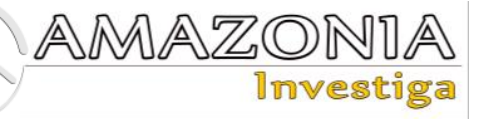

of modern Ukrainian political communication (author's abstract to obtain Ph.D. degree: special. 10.02.01 'The Ukrainian language'), the National Academy of Sciences of Ukraine. The Institute of Ukrainian Language. Kyiv. URL: http://www.irbis-nbuv.gov.ua/cgi-

bin/irbis_nbuv/cgiirbis_64.exe?Z21ID=\&I21DB $\mathrm{N}=$ REF $\&$ P21DBN $=$ REF $\&$ S2 1 STN $=1 \&$ S21REF $=10 \& S 21 \mathrm{FMT}=$ fullwebr $\& \mathrm{C} 21 \mathrm{COM}=\mathrm{S} \& \mathrm{~S} 21 \mathrm{CN}$ $\mathrm{R}=20 \& \mathrm{~S} 21 \mathrm{P} 01=0 \& \mathrm{~S} 21 \mathrm{P} 02=0 \& \mathrm{~S} 21 \mathrm{P} 03=\mathrm{A}=\& \mathrm{~S}$ $21 \mathrm{COLORTERMS}=1 \& \mathrm{~S} 21 \mathrm{STR}=\% \mathrm{D} 0 \% \mathrm{~A} 7 \% \mathrm{D}$ 0\%B0\%D0\%B4\%D1\%8E\%D0\%BA\%20\%D0 $\% 9 \mathrm{E} \$$

Chudinov, A. P. (2003). Metaphorical mosaic in modern political communication. Yekaterynburh: Ural State Pedagogical University Publishing House. URL: http://elar.uspu.ru/bitstream/uspu/5980/1/mon00 062.pdf

Chorna, N. (2011). "Anti-anxiety meds" for the electorate are forced increasing of salaries and pensions.

URL: https://news.finance.ua/ua/news/-

/239666/zaspokijlyve-dlya-elektoratu-zarplatyi-pensiyi-vymusheno-pidvyshhat

Datsyshyn, H. P. (2005). Metaphor in Ukrainian political discourse (based on modern periodicals) (author's abstract to obtain Ph.D. degree: special. 01.10.08 'Journalism'), Lviv National University named after Ivan Franko. Lviv. URL: http://www.irbis-nbuv.gov.ua/cgi-

bin/irbis_nbuv/cgiirbis_64.exe?Z21ID=\&I21DB $\mathrm{N}=\mathrm{ARD} \& \mathrm{P} 21 \mathrm{DBN}=\mathrm{ARD} \& \mathrm{~S} 21 \mathrm{STN}=1 \& \mathrm{~S} 21 \mathrm{RE}$ $\mathrm{F}=10 \& S 21 \mathrm{FMT}=$ fullwebr $\& \mathrm{C} 21 \mathrm{COM}=\mathrm{S} \& S 21 \mathrm{C}$ $\mathrm{NR}=20 \& \mathrm{~S} 21 \mathrm{P} 01=0 \& \mathrm{~S} 21 \mathrm{P} 02=0 \& \mathrm{~S} 21 \mathrm{P} 03=\mathrm{A}=\&$ $\mathrm{S} 21 \mathrm{COLORTERMS}=1 \& \mathrm{~S} 21 \mathrm{STR}=\% \mathrm{D} 0 \% 94 \%$ D0\%B0\%D1\%86\%D0\%B8\%D1\%88\%D0\%B8 $\%$ D0\%BD\%20\%D0\%A5.\%D0\%9F.\$

Davidson, D. (1990). What the metaphors mean. In Arutiunova, N. D., Zhurinskaya, M. A. (and others). Metaphor theory. Moscow: Progress, pp. 173-193.

URL: http://tlf.msk.ru/school/mikhalych/teoriya_meta fory.htm

Demchuk, S. (2015). The heart of Ukrainian corruption is the prosecutor's office. How to snatch it? URL: https://texty.org.ua/articles/61547/Serce_ukrajin skoji_korupciji_prokuratura_Jak_jogo-61547/ Economic truth (2020). Cigarette smuggling: scope, consequences, lessons learned from neighboring countries and a plan to combat. URL: https://www.epravda.com.ua/projects/nikontrabandi/2020/09/7/664652/

Economic truth (2019). Owner Louis Vuitton buys jewelry giant Tiffany for $\$ 16$ billion. URL: https://www.epravda.com.ua/news/2019/11/25/6 54075/
Filatenko, I. O. (2003). Modern political metaphor in the Russian language newspaper communication of Ukraine: cognitive and pragmatic description, (author's abstract to obtain Ph.D. degree: special. 10.02.02 'the Russian Language'), Kyiv National University named after Taras Shevchenko; Institute of Philology. Kyiv. URL: http://www.lib.uaru.net/diss/cont/31634.html

Hak, V. H. (1988). Metaphors: Universal and Specific. Metaphors in language and text. Moscow: Science, pp. 11-26. URL: https://pdf.zlibcdn.com/dtoken/16cce9d4edf282 c8c8c707acc728c2f6/Metafora_v_yazueke_i_te kste_by_Teliya_V.N._(otv._r_3094119_(zlib.org).pdf

Huzar, L. (2014). Ignoring the law seems to be a favorite sport of Ukrainian. Ukrainian truth. URL:

https://www.pravda.com.ua/columns/2014/07/4/ 7031011/

Ilchenko, O. A. (2012). Metaphorical words in the language of the Ukrainian press of the XXI century: (author's abstract to obtain Ph.D. degree: spec. 10.02.01. 'The Ukrainian language'), Kharkiv National Pedagogical University named after H. S. Skovoroda. Kharkiv. URL: http://irbis-nbuv.gov.ua/cgi-

bin/irbis_nbuv/cgiirbis_64.exe?\&I21DBN=EC

$\& \mathrm{P} 21 \mathrm{DBN}=\mathrm{EC} \& \mathrm{~S} 21 \mathrm{STN}=1 \& \mathrm{~S} 21 \mathrm{REF}=10 \& \mathrm{~S} 2$ $1 \mathrm{FMT}=$ fullwebr $\& \mathrm{C} 21 \mathrm{COM}=\mathrm{S} \& \mathrm{~S} 21 \mathrm{CNR}=20 \&$ $\mathrm{S} 21 \mathrm{P} 01=0 \& \mathrm{~S} 21 \mathrm{P} 02=0 \& \mathrm{~S} 21 \mathrm{P} 03=\mathrm{I}=\& \mathrm{~S} 21 \mathrm{COL}$ ORTERMS $=0 \& S 21 \mathrm{STR}=\% \mathrm{D} 0 \% \mathrm{~A} 0 \% \mathrm{D} 0 \% 903$ 87173

Ilchenko, O. A. (2019). Axiological markedness of contemporary mass media metaphor. Philological journal, Ed. 1 (13), pp. 42-51. DOI: https://doi.org/10.31499/2415-

8828.1.2019.169368

IMF: The world economy is between ice and flame. (2008). URL: https://www.pravda.com.ua/news/2008/07/11/3 489349/

Interfax-Ukraine, (2005). Yushchenko doesn't put pressure on Omelchenko, and Tymoshenko is on the minefield. URL: https://www.pravda.com.ua/news/2005/05/19/3 009868/

Kalymon, W. (2016). How to use e-declarations against corrupt officials. Economic truth. URL: https://www.epravda.com.ua/columns/2016/11/ 25/612344/

Kobza, M. (2019). Afghan syndrome of postMaidan Ukraine. Economic truth. URL: https://www.pravda.com.ua/columns/2019/02/1 5/7206707/

Korobkova, O. (2019). Test for Privatbank: how will the Ukrainian court and the new president make it. Economic truth. URL: 
https://www.epravda.com.ua/columns/2019/05/ 29/648236/

Kostenko, N. (2007). Geopolitical theater. "Personal Plus", № 45 (248). URL: http://www.personal-plus.net/248/2714.html

Kravets, L.V. (2012). Metaphor dynamics in the Ukrainian poetry of the XX century. Kyiv: Publishing Center "Academy". 416 p. URL: http://www.library.univ.kiev.ua/ukr/elcat/new/d etail.php3?doc_id=1448501

Kudriavtseva, L. O., Diadechko, L. P., Dorofova, O. M., Filatenko, I. O., Chernenko, H. A. (2005). Modern aspects of the advancement of mass media discourse: expression - influence - manipulation. Linguistics. Ed. 1, pp. 58-66. URL: http://arkhiv.nua.kharkov.ua/cgi-

bin/irbis64r_15/cgiirbis_64.exe?LNG=\&Z21ID $=\& I 21 \mathrm{DBN}=$ IBIS_PRINT $\&$ P21DBN=IBIS \&S2 $1 \mathrm{STN}=1 \& \mathrm{~S} 21 \mathrm{REF}=\& \mathrm{~S} 21 \mathrm{FMT}=$ fullw_print $\& \mathrm{C}$ $21 \mathrm{COM}=\mathrm{S} \& \mathrm{~S} 21 \mathrm{CNR}=\& \mathrm{~S} 21 \mathrm{P} 01=0 \& \mathrm{~S} 21 \mathrm{P} 02=1$ $\& \mathrm{~S} 21 \mathrm{P} 03=\mathrm{A}=\& \mathrm{~S} 21 \mathrm{STR}=\% \mathrm{D} 0 \% 9 \mathrm{~A} \% \mathrm{D} 1 \% 83 \%$ D0\%B4\%D1\%80\%D1\%8F\%D0\%B2\%D1\%86 $\% \mathrm{D} 0 \% \mathrm{~B} 5 \% \mathrm{D} 0 \% \mathrm{~B} 2 \% \mathrm{D} 0 \% \mathrm{~B} 0 \% 2 \mathrm{C} \% 20 \% \mathrm{D} 0 \% 9$ $\mathrm{B} \% 2 \mathrm{E} \% 20 \% \mathrm{D} 0 \% 9 \mathrm{E} \% 2 \mathrm{E}$

Kuznetsova, I. (2012). Journalists are well aware of the corrupt criminal nature of the power machine - Chaika. URL: https://www.radiosvoboda.org/a/24665995.html Lahuta, O. N. (2003). Metaphorology: theoretical aspects / Novosibirsk State University. Novosibirsk, Vol. 1. 114 p. URL: https://www.researchgate.net/publication/27394 8035_Vvedenie_Glava_1_Metaforologia_proni knovenie_v_realnost

Lakoff, J., Johnson, M. (1990). The metaphors we live by. In Arutiunova, N. D., Zhurinskaya, M. A. (and others). Metaphor theory. Moscow: Progress, pp. 387-415. URL: http://tlf.msk.ru/school/mikhalych/teoriya_meta fory.htm

Lanovyi, V. (2015). About the contagion of bankruptcy of Ukraine. Economic truth. URL: https://www.epravda.com.ua/publications/2015/ 11/3/565669/

Lanovyi, V. (2015). Gas gallows for the Ukrainian people. Economic truth. URL: https://www.epravda.com.ua/publications/2015/ 07/29/551080/

Lanovyi, V. (2016). Ice began to crack on the oligarchic pond. Economic truth. URL: https://www.epravda.com.ua/columns/2016/11/ 11/610384/

Lashchenko, O. (2020). Germany and Russia: will Berlin forget about Navalnyi and the war in Donbass? Radio Liberty. URL: https://www.radiosvoboda.org/a/germanyrussia/30825918.html
Levin, S. (1990). Pragmatic deviation of statements. In Arutiunova, N. D., Zhurinskaya, M. A. (and others). Metaphor theory. Moscow: Progress, pp. 342-357. URL: http://tlf.msk.ru/school/mikhalych/teoriya_meta fory.htm

Local elections 2020: video of the election marathon on Channel 24. (2020). URL: https://vybory.24tv.ua/mistsevi-vibori-2020ukrayina-divitisya-online-25-10-2020translyatsiya_n1438748

McKormak, E. (1990). Metaphor's cognitive theory. In Arutiunova, N. D., Zhurinskaya, M. A. (and others). Metaphor theory. Moscow: Progress, pp. 358-386. URL: http://tlf.msk.ru/school/mikhalych/teoriya_meta fory.htm

Moiseienko, O. (2019). How European banks became part of the "big laundry" for dirty money from Russia. Economic truth. URL: https://www.epravda.com.ua/publications/2019/ 03/11/645970/

Newscast TNS. Week for April 7, 2019. (2019). URL:

https://www.youtube.com/watch?v=QrxTInXU $10 \mathrm{M}$

Newscast TNS. 7.30 p.m. on July 4, 2019. URL: https://www.youtube.com/watch?v=NkqAQuFZ drM

"Political carcasses" and "puppets" stormed the parliament (VIDEO, PHOTO). (2012). URL: https://www.radiosvoboda.org/a/24751744.html Popova, T. (2018). Five "diseases" of Ukrainian voters. https://www.radiosvoboda.org/a/29271071.html Ricoeur, P. (1990). A living metaphor. In Arutiunova, N. D., Zhurinskaya, M. A. (and others). Metaphor theory. Moscow: Progress, pp. 435-455.

URL:

http://tlf.msk.ru/school/mikhalych/teoriya_meta fory.htm

Romaniuk, R. (2018). \#Hroisman's government: A game in one pocket. How Poroshenko lost the Cabinet of Ministers of Ukraine. URL: https://www.pravda.com.ua/articles/2018/12/5/7 200215/

Savchuk, T. (2017). Russia's political war in Europe: agents of chaos and who controls them (research review) URL: https://www.radiosvoboda.org/a/28716362.html Savkova, V. (2020). Price wars and pandemics at the same time: what is special about the recent fall in oil prices? URL: https://www.radiosvoboda.org/a/30480050.html Shakhnarovych, A. M., Yurieva, N. M. (1988). Metaphor's understanding problem. Metaphor in language and text. Moscow: Science, pp. 108$118 . \quad$ URL: https://pdf.zlibcdn.com/dtoken/16cce9d4edf282 


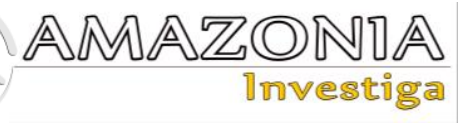

c8c8c707acc728c2f6/Metafora_v_yazueke_i_te kste_by_Teliya_V.N._(otv._r_3094119_(z-

lib.org).pdf

Shchelokov, O. (2015). Ten things to know about open data. URL: https://www.epravda.com.ua/columns/2017/04/ 21/624123/

Sierova, I. (2013). Ukrainian emigrant syndrome. URL:

https://www.pravda.com.ua/columns/2013/01/2 8/6982118/

Smolinska, V. (2019). If you are Evil, is it permitted for you? or Theatre of the absurd in Odessa.

URL: https://www.pravda.com.ua/columns/2019/01/2 9/7205204/

Solhanik, H. Ya. (1980). Lexicon of a modern newspaper. In Rosenthal, D. E. (and others). Language and style of media and propaganda. Printing. Radio. Television. Documentary film. Moscow: Moscow State University Publishing House, pp. 23-34. URL: https://search.rsl.ru/ru/record/01001023270

Solhanik, H. Ya. (1981). Newspaper vocabulary (functional aspect). Moscow: Higher School. URL:

https://search.rsl.ru/ru/record/01001066330

Stepanishyn, S. (2019). Cancer of the Ukrainian Themis.

URL:

http://volyn.rivne.com/ua/arhive/2011-07-

$01 / 1424$

Stepula, N. (2011). "Synthesized water" syndrome. $\quad$ URL: https://www.radiosvoboda.org/a/24233427.html Styshov, O. A. (2016). Unregistered in dictionaries spoken metaphor in modern Ukrainian. Scientific bulletin of [Vinnytsia State Pedagogical University named after Mykhailo Kotsiubynskyi]. Series: Philology (Linguistics). Vol. 23, pp. 47-53. URL: http://nbuv.gov.ua/UJRN/Nzvdpu_filol_2016_2 3_12.

Talko, S. V. (2016). Linguoaxiological semantics of anthropocentric metaphors and comparisons in the Ukrainian and English languages. Scientific bulletin of Kyiv National Linguistic University. Series: Philology. Ed. 19. Vol. 1, pp. 121-132. URL: http://nbuv.gov.ua/UJRN/Vknlu_fil_201 6_19_1_19

Taranenko, O. O. (2007). Metaphor. Rusanivsky, V. M., Taranenko, O. O. (and others). Ukrainian language: encyclopedia. 3rd ed. with changes and ext. Kyiv: 'Ukrainian encyclopedia named after M. P. Bazhan', pp. 350-353.

Teliia, V. N. (1988). Metaphor as a model of meaning production and its expressive and evaluative function. Metaphor in language and text. Moscow: Science, pp. 26-51. URL: https://ua1lib.org/book/3094119/6f8a04?id=309
$4119 \&$ secret $=6 f 8 \mathrm{a} 04$

The United States supported Ukraine before the Normandy meeting. (2019). URL: https://ua.korrespondent.net/world/4169109ssha-pidtrymaly-ukrainu-pered-normandskouizustrichchui

Tribune (2017). Anatomy of bribery provocation from Transcarpathian law enforcement officers (video).

URL:

https://trubyna.org.ua/novyny/anatomiyaprovokatsiyi-habarya-vid-zakarpatskyhpravoohorontsiv-video/

Tymoshenko, D. (2020). "War is not a passion. This is my native pain "- a photojournalist who filmed Maidan and Donbass. URL: https://www.radiosvoboda.org/a/31013653.html Tymoshenko will arrange a budget "storm" for Yatseniuk before the holidays. (2008). URL: https://www.pravda.com.ua/news/2008/07/4/34 83221/

Ukraine expects to start revising the Association Agreement with the EU - Ministry of Economy. (2020).

URL:

https://www.epravda.com.ua/news/2020/05/22/6 60860/

Ukrainian language: encyclopedia (2004), ed.: V. M. Rusanivskyi (and others). Kyiv: M. P. Bazhan Ukrainian encyclopedia, pp. 334-336. URL: http://irbis-nbuv.gov.ua/cgi-

bin/ua/elib.exe?Z21ID=\&I21DBN=UKRLIB \&P $21 \mathrm{DBN}=\mathrm{UKRLIB} \& \mathrm{~S} 21 \mathrm{STN}=1 \& \mathrm{~S} 21 \mathrm{REF}=10 \&$ $\mathrm{S} 21 \mathrm{FMT}=$ online book $\& \mathrm{C} 21 \mathrm{COM}=\mathrm{S} \& \mathrm{~S} 21 \mathrm{CNR}$ $=20 \& S 21 \mathrm{P} 01=0 \& S 21 \mathrm{P} 02=0 \& \mathrm{~S} 21 \mathrm{P} 03=\mathrm{FF}=\& \mathrm{~S} 2$ $1 \mathrm{STR}=\mathrm{ukr} 0000790 \% 5 \mathrm{~F} 1$

Volska, O. (2019). Will Ukraine be covered by an investment storm in 2019. URL: https://www.epravda.com.ua/columns/2019/03/ 13/646029/

Vynnyk, O. P. (2007). Metaphorical processes in the formation of Ukrainian economic vocabulary: author's abstract to obtain Ph.D. degree: special. 10.02.01 'The Ukrainian language' / Kharkiv National Pedagogical University named after H.S. Skovoroda. Kharkiv. URL: http://catalog.odnb.odessa.ua/opac/index.php?ur l=/notices/index/IdNotice: $181579 /$ Source:defaul $\mathrm{t}$

Tertychna, S. (2003). On the eve of the vodka war. URL: https://zn.ua/ukr/business/naperedodni_gorilcha noyi_viyni.html

Trump compared a female senator to a snowman. (2019).

URL: https://ua.korrespondent.net/world/4063596tramp-porivniav-zhinku-senatora-zisnihovykom

Volyn News Agency (2014). "Donetsk-Luhansk syndrome": What about our guys who survived 
the anti-terrorist operation URL: https://www.volynnews.com/news/society/donet sko-luhanskyy-syndrom-shcho-z-nashymy-

khloptsiamy-iaki-vyzhyly-v-ato/

War in the east: 12 shellings per day, 1 fighter killed, 1 wounded. (2019). URL: https://www.pravda.com.ua/news/2019/06/6/72 17273/
Yeshchenko, T. A. (1999). Metaphor: from structural analysis to functional-cognitive. Linguistic studios. Donetsk: DonNU, Ed. 5, pp. 276-278. URL: https://scholar.google.com.ua/citations?user=Eq wMNzsAAAAJ\&hl=ru\&oi=sra 